\title{
Evaluation of Performance in Female Madura Cattle in Madura Island, Indonesia
}

\author{
Veronica Margareta Ani Nurgiartiningsih ${ }^{1 *}$, Agus Budiarto ${ }^{1}$, Kusmartono $^{2}$, Suyadi ${ }^{1}$ \\ ${ }^{1}$ Department of Animal Production, Faculty of Animal Husbandry, University of Brawijaya, Malang 65145, Indonesia \\ ${ }^{2}$ Department of Animal Nutrition, Faculty of Animal Husbandry, University of Brawijaya, Malang 65145, Indonesia \\ *Corresponding author email: vm_ani@yahoo.com/vm_ani@ub.ac.id
}

\begin{abstract}
This research was conducted to evaluate the performance of female Madura cattle in three districts of Madura Island (Sampang, Pamekasan, and Sumenep), known as breeding areas for purebred Madura cattle. Vital statistics of 1,040 female Madura cattle at 24 and 30 months old in Sampang, Pamekasan, and Sumenep district were measured and analysed. Mean of Body weight, chest girth, body length, and wither height of female Madura cattle at 24 months old were $191.7 \pm 17.6 \mathrm{~kg}, 133 \pm 3.0 \mathrm{~cm}, 124.0 \pm 2.1 \mathrm{~cm}, 115.7 \pm 2.9 \mathrm{~cm}$, respectively, and those at 30 months old were $209.4 \pm 23.6 \mathrm{~kg}, 138.2 \pm 4.5 \mathrm{~cm}, 125.7 \pm 2.6 \mathrm{~cm}, 116.7 \pm 3.4 \mathrm{~cm}$, respectively. The body weight, chest girth, body length of female Madura cattle at 24 and 30 months old in Pamekasan district $(216.6 \pm 26.5 \mathrm{~kg}, 135.2 \pm 6.1 \mathrm{~cm}, 125.4 \pm 3.9 \mathrm{~cm}$, and $238.0 \pm 28.5 \mathrm{~kg}, 141.5 \pm 6.7 \mathrm{~cm}, 127.9 \pm 3.5$ $\mathrm{cm}$, respectively) showed the highest value compared to those in Sampang and Sumenep district. Phenotypic correlation between vital statistics and body weight at 24 and 30 months old ranged between -0.43 to 0.90 . Chest girth showed the positive highest correlation with body weight of female Madura cattle at 24 months old (0.24) and at 30 month old (0.90). It indicated that chest girth could be used as estimation parameter for body weight in female Madura cattle.
\end{abstract}

Key words: body weight, chest girth, body length, wither height, phenotypic correlation

Abstrak. Penelitian ini dilakukan untuk mengevaluasi performan Sapi Madura betina di tiga kabupaten di Pulau Madura (Sampang, Pamekasan, dan Sumenep), yang dikenal sebagai wilayah sumber bibit Sapi Madura murni. Ukuran tubuh Sapi Madura betina pada umur 24 dan 30 bulan sebanyak 1.040 dari kabupaten Sampang, Pamekasan, dan Sumenep diukur dan dianalisis. Rataan bobot badan, lingkar dada, panjang badan, dan tinggi badan Sapi Madura betina umur 24 bulan adalah 191,7 $\pm 17,6 \mathrm{~kg}, 133 \pm 3,0 \mathrm{~cm}, 124,0 \pm 2,1 \mathrm{~cm}$, $115,7 \pm 2,9 \mathrm{~cm}$, dan untuk umur 30 bulan adalah $209,4 \pm 23,6 \mathrm{~kg}, 138,2 \pm 4,5 \mathrm{~cm}, 125,7 \pm 2,6 \mathrm{~cm}, 116,7 \pm 3,4 \mathrm{~cm}$. Rataan bobot badan, lingkar dada, panjang badan Sapi Madura betina umur 24 dan 30 bulan di Kabupaten Pamekasan $(216,6 \pm 26,5 \mathrm{~kg}, 135,2 \pm 6,1 \mathrm{~cm}, 125,4 \pm 3,9 \mathrm{~cm}$, dan $238,0 \pm 28,5 \mathrm{~kg}, 141,5 \pm 6,7 \mathrm{~cm}, 127,9 \pm 3,5 \mathrm{~cm})$ menunjukkan nilai tertinggi dibandingkan dengan ukuran Sapi Madura betina di Kabupaten Sumenep dan Sampang. Korelasi fenotip antara ukuran tubuh dan bobot badan pada Sapi Madura betina umur 24 dan 30 bulan berkisar -0,43 sampai 0,90. Lingkar dada menunjukkan korelasi positip tinggi dengan bobot badan sapi Madura betina pada umur 24 bulan $(0,24)$ dan pada umur 30 bulan $(0,90)$. Hal ini menggambarkan bahwa lingkar dada dapat digunakan sebagai parameter estimasi untuk bobot badan Sapi Madura betina.

Kata kunci: bobot badan, lingkar dada, panjang badan, tinggi badan, korelasi fenotip

\section{Introduction}

Madura cattle are a local beef cattle breed originating from the island of Madura near north-eastern Java and believed to be developed from Bali cattle (Bos (bibos) spp), Bos indicus and Bos Taurus (Payne and Rollinson, 1976). Nijman et al. (2003) reported that Madura cattle carried mitochondrial DNA of either, Zebu (Bos indicus) and Banteng (Bos javanicus) origin. The reddish brick-brown Madura cattle have a non-specific white pattern on the back-bottom. Madura cattle were categorized into small to medium beef cattle type (Setiadi and Diwyanto, 1997). The advantages of Madura cattle were good growth in poor quality of forage, high carcass percentage with good meat quality, and high adaptability to tropical environments (Sutarno and Setyawan, 2015). Kutsiyah et al. (2003) and Hartatik et al. (2009) reported, that Madura cattle has good reproductive performance with short calving interval and low service per conception. 
Most of Madura cattle are kept in Madura Island spread over four districts, namely Sumenep, Pamekasan, Sampang and Bangkalan. Generally, local Madura cattle are kept as a capital asset (security) and as additional household income, besides the main income from cropping (Siswijono et al., 2010). In addition to those objectives, there are specific cultural purposes, namely bull racing (Karapan) and dancing/festive cattle (Sonok). Riszqina et al. (2014) reported that Madura cattle are raised for beef / draught, racing (karapan) and beauty contest (sonok). These traditions play an important role to conserve Madura cattle as local Indonesian breed. Widi et al. (2013) reported that crossbreeding would not directly influence the cultural events or the management practices of Madura cattle in the karapan and sonok area because crossbred cattle are not suitable to participate in these cultural events.

Madura cattle in Madura contributed high value, reached $24 \%$, of the needs of beef cattle originating from East Java. Central Statistics Agency of East Java (2014) recorded the cattle population in the four districts in the Madura island occupied 806,608 in 2013, increased $2.44 \%$ compared to 2012 which only reached 787,424 . This value indicated that Madura cattle in Madura Island played an important role in national meat production. An increasing number of Madura cattle in Madura Island did not directly effect on increasing number of pure Madura cattle, due to the application of crossbreeding. For over ten years, crossbreeding using artificial insemination of Limousine has been executed in Madura Island. In 2010, the crossbred cattle occupied already $53.5 \%$ of the population in Madura Island (Nurgiartiningsih, 2010). Crossbreeding is believed to be the most dangerous threat for local breeds in Indonesia with its consequences loss of adaptability (fertility, calf mortality, and disease) (Widi et al., 2013). Crossbred of Limousin and Madura cattle showed steril male and lower reproductive capacity compared to the parents (Sutarno and Setyawan, 2015). It is also important to note that most breeding of purebred Madura cattle in Madura island $(82.7 \%)$ is by natural mating using Madura bulls and only $17.2 \%$ of Madura cattle are inseminated artificially using semen of Madura cattle (Nurgiartiningsih, 2010). Madura farmers believe that by applying natural mating the specific traits of Madura cattle can be maintained. Considering the limited number of Madura bulls available for mating in the area and lack of recording, there is a high risk of inbreeding. This condition will lead to a considerable reduction in the genetic variation, which is the basic for genetic improvement.

Continuous crossbreeding of Madura cattle will significantly decrease the number of purebred female Madura cattle in the population, which will affect the availability of replacement stock. The increasing population number of Madura cattle depends on the number of productive females and the genetic potency of females, which could be expressed by the performance. The government policy played an important role in the improvement of Madura cattle as local genetic resources in Madura Island. Since 2013, Indonesian National Standard for Madura cattle, consisted of a minimum quantitative requirement for chest girth, body length and wither height in pure Madura cattle has been published by National Standardization Agency of Indonesia (2013). The standard was used for selection criteria of bulls and cows. Based on the Indonesian National Standard, quantitative requirements for breeding of Madura cattle are grouped into three classes (grades one, two and three) each for chest girth, body height and body length in Madura cattle at the age of 12-18 months, 1824 months and 24-36 months.

Sampang, Pamekasan and Sumenep districts in Madura Island showed high potential as a source of purebred Madura cattle. Those districts were very important for conservation 
and breeding area of pure Madura cattle. Based on the condition in Madura Island and the important of Madura cattle as genetic resources of Indonesia, this research was conducted to evaluate the performance of female Madura cattle in three districts in Madura Island, as an important factor to maintain and improve the genetic potency and the population of purebred Madura cattle population.

\section{Materials and Methods}

The survey and data recording was done in Sampang, Pamekasan and Sumenep District, Madura Island, East Java province, Indonesia. Female Madura cattle aging of 24 and 30 months old in Sampang (308), Pamekasan (222) and Sumenep (510) were measured for body weight, chest girth, body length and wither height. The data used were collected in the period of August to October 2013 and data of performance test in 2013 done by Technical Implementation Unit of Madura Cattle, The East Java Livestock Services. Body weights were measured by using a weighing scale, chest girths were measured by using measurement tape, while body length and wither height were measured using measurement stick. The animals were kept by 474 farmers and were purposively selected as samples for the three districts assigned under the guidance of Livestock services institution in each district. Data was analysed using ANOVA one-way classification to evaluate the performance of Madura cattle in a different district in Madura Island. The statistical model was as follows:

$$
Y_{i j}=\mu+\tau_{i}+E_{i j}
$$

$Y_{i j}=$ Performance (body weight, chest girth, body length or wither height) of $\mathrm{j}$ individual and $\mu=$ population mean; $\tau_{i}=$ fixed effect of $\mathrm{i}$ district; $E_{i j}=$ error.

Correlations between two variables were estimated using simple linear regression applying software GENSTAT release 16 (VSN International, Ltd., 2015). The formula for correlation was:

$$
r=\frac{\operatorname{cov}_{x y}}{\sigma_{x} \sigma_{y}}
$$

$r=$ correlation coefficient; $\operatorname{cov}_{\mathrm{xy}}=$ covariance of $\mathrm{X}$ and $\mathrm{Y}$ variable; $\sigma_{x}=$ standard error of $\mathrm{X} ; \sigma_{y}$ $=$ standard error of $\mathrm{Y}$.

\section{Results and Discussion}

Mean of body weights, chest girths, body lengths and wither heights of female Madura cattle at 24 months old in Sampang, Pamekasan and Sumenep district were presented in Table 1.

The overall mean of chest girth, body length and wither height at $\mathbf{2 4}$ months old of females Madura cattle in Madura island, as seen in Table 1, were $133.6 \pm 3.0 \mathrm{~cm}, 124.0 \pm 2.1 \mathrm{~cm}$, and $115.7 \pm 2.9 \mathrm{~cm}$, respectively. Those performances showed higher value compared to the previous study by Harmadji (1992), which reported that chest girth, body length and wither height at 24 months old were 128.86, 103.59 and $112.18 \mathrm{~cm}$, respectively.

Table 1. Means and standard deviations of Body Weight, Chest Girth, Body Length, and Wither Height at 24 months old of Female Madura cattle in Sampang, Pamekasan and Sumenep, Madura Island.

\begin{tabular}{lccccc}
\hline District & $\mathrm{N}$ & Body Weight $(\mathrm{kg})$ & $\begin{array}{c}\text { Chest Girth } \\
(\mathrm{cm})\end{array}$ & $\begin{array}{c}\text { Body Length } \\
(\mathrm{cm})\end{array}$ & Wither Height $(\mathrm{cm})$ \\
\hline Sampang & 232 & $185.1 \pm 6.48^{\mathrm{a}}$ & $133.0 \pm 1.22^{\mathrm{a}}$ & $124.2 \pm 1.35^{\mathrm{a}}$ & $116.8 \pm 1.34^{\mathrm{a}}$ \\
Pamekasan & 109 & $216.6 \pm 26.53^{\mathrm{b}}$ & $135.2 \pm 6.09^{\mathrm{b}}$ & $125.4 \pm 3.86^{\mathrm{b}}$ & $111.0 \pm 3.52^{\mathrm{b}}$ \\
Sumenep & 259 & $187.3 \pm 8.23^{\mathrm{c}}$ & $133.6 \pm 1.72^{\mathrm{a}}$ & $124.3 \pm 1.36^{\mathrm{a}}$ & $116.8 \pm 1.51^{\mathrm{a}}$ \\
\hline Overal Mean & 600 & $191.7 \pm 17.6$ & $133.6 \pm 3.0$ & $124.0 \pm 2.1$ & $115.7 \pm 2.9$ \\
\hline $\mathrm{P}$ & & $<0.001$ & $<0.001$ & $<0.001$ & $<0.001$ \\
\hline
\end{tabular}


This indicated that compared to about 25 years ago, performances of female Madura cattle increased $4.7 \mathrm{~cm}$ (3.7\%) in chest girth, $20.4 \mathrm{~cm}$ (19.7\%) in body length and $3.52 \mathrm{~cm}$ (3.1\%) in whither height. The present body weight of Madura cattle at two years old $(191.7 \pm 26.53 \mathrm{~kg})$ was also higher than those of Madura cattle in Kalimantan Island, Indonesia, which was $169.8 \mathrm{~kg}$ (Ngadiyono et al. 2000). The different value was due to the different environment, feed availability and husbandry system. These increases in body weight and vital statistics were due to better genetic performance resulted from better breeding and feeding management. Most of the farmer in Madura Island has the knowledge of selection for breeding their Madura cattle by choosing the superior bull for natural mating and good quality semen for artificial insemination. Most of Madura farmer treated their Madura cattle as family and give special treatment in feeding by giving additional feed.

Mean of body length $(124.0 \pm 2.1 \mathrm{~cm})$ and wither height $(115.7 \pm 2.9 \mathrm{~cm})$ of female Madura cattle at 24 months old were respectively categorized in grade two and grade three of Indonesian National Standard for female Madura cattle at $18-<24$ months old, which the minimal value were $123 \mathrm{~cm}$ and $114 \mathrm{~cm}$, respectively (National Standardization Agency of Indonesia, 2013). It indicated that the performance of female Madura cattle in three districts of Madura Island could be used as breeding female for producing the next generation.
Mean of body weights, chest girths, body lengths and wither heights of female Madura cattle at 30 months old in three districts (Sampang, Pamekasan and Sumenep) were presented in Table 2. Mean of body length of female Madura cattle at 30 months old in this study $(125.7 \pm 2.55 \mathrm{~cm})$ was categorized in grade three of Indonesian National Standard, which was $125 \mathrm{~cm}$ (National Standardization Agency of Indonesia, 2013). Mean of chest girth $(138.2 \pm 4.51 \mathrm{~cm})$ and wither height $(116.7 \pm 3.45$ $\mathrm{cm}$ ) were lower than grade three of Indonesian National Standard. This condition indicated that improvement of performance must be done by application of the good breeding program, especially selection based on breeding value to achieve better performance.

The statistical analysis on body weight and vital statistics of Madura cattle at 24 and 30 months old showed high significant different $(P<0.001)$ between districts. The highest values for body weight, chest girth, and body length were found in Pamekasan, compared to the values in Sampang and Sumenep district. This result was in agreement with Nurgiartiningsih (2011) reported that Pamekasan district showed the highest performance of Madura cattle at 12 months old. The highest cow's performance in Pamekasan was related to the high genetic potency of Madura cattle and the availability of feed resources in the area. Pamekasan has high potency in agriculture by products, such as rice straw, vegetables and legume trees.

Table 2. Mean and Standard Deviation of Body Weight, Chest Girth, Body Length, and Wither Height at 30 months old of Female Madura cattle in Sampang, Pamekasan and Sumenep, Madura Island

\begin{tabular}{llcccc}
\hline District & $\mathrm{N}$ & $\begin{array}{c}\text { Body Weight } \\
(\mathrm{kg})\end{array}$ & $\begin{array}{c}\text { Chest Girth } \\
(\mathrm{cm})\end{array}$ & $\begin{array}{c}\text { Body Length } \\
(\mathrm{cm})\end{array}$ & $\begin{array}{c}\text { Wither Height } \\
(\mathrm{cm})\end{array}$ \\
\hline Sampang & 76 & $195.6 \pm 6.68^{\mathrm{a}}$ & $134.7 \pm 0.95^{\mathrm{a}}$ & $124.2 \pm 1.39^{\mathrm{a}}$ & $116.7 \pm 1.39^{\mathrm{a}}$ \\
Pamekasan & 113 & $238.0 \pm 28.46^{\mathrm{b}}$ & $141.5 \pm 6.72^{\mathrm{b}}$ & $127.9 \pm 3.46^{\mathrm{b}}$ & $112.0 \pm 3.06^{\mathrm{c}}$ \\
Sumenep & 251 & $200.6 \pm 10.23^{\mathrm{a}}$ & $137.7 \pm 2.55^{\mathrm{c}}$ & $125.2 \pm 1.53^{\mathrm{a}}$ & $118.8 \pm 1.76^{\mathrm{a}}$ \\
\hline Overal Mean & 440 & $209.4 \pm 23.6$ & $138.2 \pm 4.51$ & $125.7 \pm 2.55$ & $116.7 \pm 3.45$ \\
\hline P & $<0.001$ & $<0.001$ & $<0.001$ & $<0.001$ \\
\hline
\end{tabular}


The most striking feature of Pamekasan district is the multi-layered soil with relatively high fertility rates. Tobacco was grown widely in Pamekasan and for almost all farmers; tobacco was of high economic value and increased the living standards of the farmers in Pamekasan district (Central Statistics Agency of East Java, 2014). The better economic condition of the farmer might have a significant effect on better management of the cattle. Pamekasan district has been well known as a source of sonok cattle and the bull racing animals.

The genetic progress of female Madura cattle in Madura Island has shown some improvements in performance. This condition of female could be used as basic population for performance test and breeding program to achieve improvement in genetic quality. Government support should be needed for implementation of those programs, considering Madura Island as an area for breeding and conservation of Madura cattle as local genetic resources of Indonesia.

The phenotypic correlations between body weight, chest girth, body length and body height of female Madura cattle in Madura Island were shown in Table 3.

Table 3. Correlation between body weight, chest girth, body length and body height at 24 months old (above diagonal) and 30 months old (below diagonal) in female Madura cattle

\begin{tabular}{lllll}
\hline TRAITS & $\begin{array}{l}\text { Body } \\
\text { weight }\end{array}$ & $\begin{array}{l}\text { Chest } \\
\text { girth }\end{array}$ & $\begin{array}{l}\text { Body } \\
\text { length }\end{array}$ & $\begin{array}{l}\text { Body } \\
\text { height }\end{array}$ \\
\hline $\begin{array}{l}\text { Body } \\
\text { weight }\end{array}$ & & 0.42 & 0.27 & -0.43 \\
$\begin{array}{l}\text { Chest } \\
\text { girth }\end{array}$ & 0.90 & & 0.39 & -0.10 \\
$\begin{array}{l}\text { Body } \\
\text { length }\end{array}$ & 0.66 & 0.55 & & 0.09 \\
$\begin{array}{l}\text { Body } \\
\text { height }\end{array}$ & -0.54 & -0.29 & -0.24 & \\
\hline
\end{tabular}

As seen in Table 3, most of the correlation estimates were highly significantly different from zero $(P<0.001)$, except for the correlation value for body height with chest girth and body weight with body length at 24 months old, which were significant at $\mathrm{P}=0.02$ and $\mathrm{P}=0.03$, respectively. Phenotypic correlation between chest girth with body weight and body length with body weight were respectively, 0.42 and 0.27 for 24 months old and 0.90 and 0.66 for 30 months old. Those values were positive, indicating that improvement of chest girth and body length would also improve the body weight.

The highest correlation was found between chest girth and body weight at 30 months old, which was 0.90. This result was in agreement with the result obtained by Ni'am et al. (2012) who found the correlation between chest girth and body weight in Bali cattle was 0.92. Nurgiartiningsih (2011) found the smaller value for correlation between chest girth and body weight at 5 months old, which was 0.69 . The regression analysis showed that there was a highly significant regression of chest girth on body weight $(P<0.001)$. The correlation estimates between chest girth and body weight were higher than correlation estimates between body lengths and wither height with body weight. Cow body weight is one indicator for livestock productivity, which can be predicted by the size of the linear body of the cow. The high correlation indicated that chest girth could be used as a parameter for estimating body weight of female Madura cattle.

\section{Conclusions}

The body weight, chest girth, body length of female Madura cattle at 24 and 30 months old in Pamekasan district were higher than those in Sampang and Sumenep district. The correlation between chest girth and body weight of female Madura cattle at 30 month old showed the highest value, which indicated that chest girth could be used as estimation parameter for body weight in female Madura cattle. 


\section{Acknowledgements}

This research was supported by research grant from The East Java Livestock Services in 2013. We thank the staff of Technical Implementation Unit of Madura Cattle, East Java Province and staff of Livestock services in Madura for data collection. We also thank the farmers in Sampang, Pamekasan and Sumenep district, Madura Island for their willingness to supply samples of their cattle.

\section{References}

Central Statistics Agency of East Java. 2014. Annual Report of 2013.

Harmadji. 1992. Development Prospect of Madura Cattle. In: Ma'sum, K., Yusran, M.A. and Rangkuti, M. (eds) Proceedings of Scientific Meeting on the Research and Development in Madura Cattle, Pp. 59-66.

Hartatik, T, DA Mahardika, TSM Widi, and E Baliarti. 2009. Characteristics and Performance of Limousin-Madura Grade and Madura Cows in Sumenep and Pamekasan Regencies). Bulletin of Animal Science (Buletin Peternakan) 33(3):143147.

Kutsiyah, F, Kusmartono, and T Susilawati. 2003. Comparative Study in productivity of Madura cattle and its crosses with Limousin in Madura Island. Journal of Animal Science and Veterinary (Jurnal Ilmu Ternak dan Veteriner 8(2):98-106.

National Standardization Agency of Indonesia. 2013. Beef Cattle - Madura Cattle, SNI 7651.2:2013.

Ngadiyono, N, H Hartardi, W Winugroho, DD Siswansyah and SN Ahmad. 2000. Effect of Bioplus on Performance of Madura Cattle in Central Kalimantan. Journal of Animal Science and Veterinary 6(2):69-75

Ni'am, HUM, A Purnomoadi and S Dartosukarno. 2012. Correlation between statistic vital and body weight in female Bali cattle at different age group. Agriculture Animal Journal 1 (1): 541-556.

Nijman, IJ, M Otsen, EL Verkaar, C de Ruijter, E Hanekamp, JW Ochieng, S Shamshad, JE Rege, O Hanotte, MW Barwege, T Sulawati, JA Lenstra. 2003. Hybridization of banteng (Bos javanicus) and zebu (Bos indicus) revealed by mitochondrial DNA, satellite DNA, AFLP and microsatellites. Heredity 90 (1):10-16.

Nurgiartiningsih, VMA. 2010. Breeding system and performance of crossbred Madura cattle in Madura Island, Madura. Journal of Tropical Animal Production (Jurnal Ternak Tropika) 11:2331.

Nurgiartiningsih, VMA. 2011. Map of Genetic potency of Pure Madura Cattle at Four Districts in Madura. Journal of Tropical Animal Production (Jurnal Ternak Tropika) 12(2):23-32.

Payne, WJA and DHL Rollinson. 1976. Madura Cattle. Z Tierzuecht. Zuechtsbiol 93: 89-100.

Riszqina, Isbandi, E Rianto and SI Santoso. 2014. Income of Madura cattle farmers in Madura island of East Java province of Indonesia. Bangladesh Journal Animal Science 43(1):68-73.

Setiadi, B and K Diwyanto. 1997. Characterization in morphology of Madura cattle. Journal of Animal Science and Veterinary (Jurnal IImu Ternak dan Veteriner) 4:218-224.

Siswijono SB, I Subagiyo, VMA Nurgiartiningsih, Kusmartono, Hartutik, Tadjuddin. 2010. Perception of Madurese community on crossbreeding program of limousine and native Madura beef cattle in Madura Island of Indonesia. 9th World Congress on Genetics Applied to Livestock Production, Leipzig, Germany, August 1-6, 2010.

Sutarno and D Setyawan. 2015. Genetic diversity of local and exotic cattle and their crossbreeding impact on the quality of Indonesia cattle. Biodiversitas 16 (2):327-354

VSN International Ltd. 2015. GENSTAT Release 16.

Widi, T.S.M., HMJ Udo, JK Oldenbroe, IGS Budiastra, E Baliarti, AJ van Zijpp. 2013. Unique cultural values of Madura cattle: is crossbreeding a threat? Animal Genetic Resource 54:141-152. 